\title{
Dietary egg-white protein increases body protein mass and reduces body fat mass through an acceleration of hepatic $\beta$-oxidation in rats
}

\author{
Ryosuke Matsuoka $^{1} \dagger$, Bungo Shirouchi $^{2} \dagger$, Minami Umegatani ${ }^{2}$, Meguri Fukuda $^{2}$, Ayano Muto $^{1}$, \\ Yasunobu Masuda $^{1}$, Masaaki Kunou ${ }^{1}$ and Masao Sato ${ }^{2 *}$ \\ ${ }^{1}$ RED Division, Kewpie Corporation, Sengawa Kewport, 2-5-7 Sengawa-cho, Chofu-shi, Tokyo, 182-0002, Japan \\ ${ }^{2}$ Laboratory of Nutrition Chemistry, Department of Bioscience and Biotechnology, Faculty of Agriculture, Graduate School, \\ Kyushu University, 6-10-1 Hakozaki, Higashi-ku, Fukuoka 812-8581, Japan
}

(Submitted 16 February 2017 - Final revision received 8 June 2017 - Accepted 31 July 2017)

\section{Abstract}

Egg-white protein (EWP) is known to reduce lymphatic TAG transport in rats. In this study, we investigated the effects of dietary EWP on body fat mass. Male rats, 4 weeks old, were fed diets containing either $20 \%$ EWP or casein for $28 \mathrm{~d}$. Carcass protein levels and gastrocnemius leg muscle weights in the EWP group were significantly higher than those in the casein group. In addition, carcass TAG levels and abdominal fat weights in the EWP group were significantly lower than those in the casein group; adipocyte size in abdominal fat in the EWP group was smaller than that in the casein group. To identify the involvement of dietary fat levels in the rats, one of two fat levels (5 or $10 \%)$ was added to their diet along with the different protein sources (EWP and casein). Abdominal fat weight and serum and hepatic TAG levels were significantly lower in the EWP group than in the casein group. Moreover, significantly higher values of enzymatic activity related to $\beta$-oxidation in the liver were observed in the EWP group compared with the casein group. Finally, abdominal fat weight reduction in the EWP group with the $10 \%$ fat diet was lower than that in the EWP group with the $5 \%$ fat diet. In conclusion, our results indicate that, in addition to the inhibition of dietary TAG absorption reported previously, dietary EWP reduces body fat mass in rats through an increase of body protein mass and the acceleration of $\beta$-oxidation in the liver.

Key words: Egg-white protein: Adipocyte size: Body composition: $\beta$-Oxidation: Rats

Proteins serve numerous nutritional functions in the body, contributing to essential structural components and enzymes, as well as providing the base materials for hormones and assisting in immunity ${ }^{(1)}$. Importantly, protein deficiency has been reported to be one of the causes of sarcopenia ${ }^{(2)}$. Because there is a negative correlation between the number of sarcopenia patients and the amount of protein ingested in the diet ${ }^{(3)}$, it is important to consume foods high in protein to maintain and increase muscle. However, the ingestion of large amounts of protein for middle-aged and elderly individuals can be difficult. Furthermore, because proteins are used in different ways throughout the body depending on their source ${ }^{(4)}$, it is important to ingest protein that can contribute appropriately to muscle health.

Egg whites are a fat-free, high-protein food. Egg-white protein (EWP) contains many essential amino acids, having an amino acid score of 100 , and is a high-quality source of protein compared with proteins derived from milk and soyabeans ${ }^{(5)}$. EWP also has a higher net protein utilisation than these proteins and other proteins with an amino acid score of $100^{(6)}$. In this study, we focused on EWP as one such source. Recently, because of changes in lifestyle habits, an increase in abdominal fat has become prevalent and has been found to lead to dyslipidaemia, hypertension and impaired glucose tolerance, eventually escalating to the metabolic syndrome, which can cause atherosclerotic disease ${ }^{(7)}$. Approximately $50 \%$ of adult Japanese men have the metabolic syndrome or are at an increased risk for this condition ${ }^{(8)}$. Aside from water, the human body primarily consists of proteins and lipids ${ }^{(9)}$. Therefore, it is hypothesised that increasing body protein can lower body fat proportion and abdominal fat levels and prevent or reduce the incidence of the metabolic syndrome.

Most studies reporting a decrease in abdominal fat because of the consumption of functional foods have identified physiologically active substances contributing to this reduction, such as catechins ${ }^{(10)}$ and polyphenols ${ }^{(11)}$, and it has also been reported that medium-chain fatty acids have an abdominal-fatlowering effect ${ }^{(12)}$. Importantly, a relationship between protein ingestion and visceral fat reduction is indicated by consumption

\footnotetext{
Abbreviation: EWP, egg-white protein.

* Corresponding author: M. Sato, fax +8192642 3004, email masaos@agr.kyushu-u.ac.jp

$\dagger$ These authors contributed equally to this work.
} 
of lactoferrin, a protein fraction contained in milk, which has been shown to decrease visceral fat ${ }^{(13)}$. In addition, the soyabean protein fraction, $\beta$-conglycinin, has been reported to lower serum TAG concentrations ${ }^{(14)}$. Therefore, protein consumption can potentially lead to a decrease in visceral fat. However, in the nutritional protein research field, the effect of EWP on abdominal fat levels has not been investigated.

Here, we investigated the effect of EWP on body protein and body fat. In addition, we assessed the effect of EWP on abdominal fat accumulation and sought to identify the suppressive mechanism of EWP on abdominal fat accumulation.

\section{Methods \\ Materials}

EWP was obtained from the Kewpie Egg Corporation. Casein was purchased from Oriental Yeast Co. Ltd. The protein content was determined by the Dumas method (Association of Official Analytical Chemists official method 968.06) and calculated as the nitrogen content $\times 6 \cdot 25^{(15)}$. The measured protein content was $85.9 \%$ for the casein group and $86.1 \%$ for the EWP group. The amino acid composition of EWP and casein was analysed with an automatic amino acid analyser JLC-500/V (JEOL Ltd); results are shown in Table 1 .

\section{Animals and diets}

Male Sprague-Dawley rats (Slc:SD), 4 weeks old, were obtained from Japan SLC Inc. The rats were housed individually in an airconditioned room $\left(22-24^{\circ} \mathrm{C}\right)$ at $50 \%$ humidity on a $12 \mathrm{~h}$ light$12 \mathrm{~h}$ dark cycle (light from 08.00-20.00 hours). Before the experiment, all rats were permitted free access to AIN-76 diets $^{(16)}$ for $3 \mathrm{~d}$. Experimental diets were also prepared according to the AIN-76 formulation. The compositions of experimental diets are shown in Table 2 . Body weight and food intake of rats in Expts 1-3 were recorded every day.

For Expt 1, the rats were fed either the casein ( $n 10)$ or EWP diet ( $n$ 10) and provided feed containing $10 \%$ maize oil

Table 1. Amino acid composition of casein and egg-white protein (EWP)

\begin{tabular}{lcc}
\hline & Casein (\%) & EWP $(\%)$ \\
\hline Asp & 6.54 & 9.91 \\
Thr & 4.00 & 4.43 \\
Ser & 5.08 & 6.39 \\
Glu & 18.8 & 12.1 \\
Pro & 9.93 & 3.39 \\
Gly & 1.69 & 3.39 \\
Ala & 4.96 & 7.04 \\
Val & 6.30 & 6.78 \\
Cys & 0.48 & 2.74 \\
Met & 2.78 & 3.91 \\
lle & 4.96 & 5.22 \\
Leu & 8.84 & 8.21 \\
Tyr & 5.45 & 3.65 \\
Phe & 4.72 & 5.87 \\
Lys & 7.99 & 7.17 \\
His & 2.66 & 2.35 \\
Trp & 1.33 & 1.56 \\
Arg & 3.51 & 5.87 \\
Amino acid score (\%) & 100 & 100 \\
\hline
\end{tabular}

(Table 2) for $28 \mathrm{~d}$ using a pair-feeding protocol. At the end of the final study day, the rats were subjected to 8-h fasting, anaesthetised with isoflurane (Intervet K.K.) and then killed via cervical dislocation and their carcasses were analysed.

For Expt 2, the rats were fed the casein ( $n$ 10) or EWP diet ( $n$ 9) and provided feed containing $10 \%$ maize oil (Table 2 ) for $28 \mathrm{~d}$ using a pair-feeding protocol. At the end of the final study day, the rats were subjected to 8-h fasting, anaesthetised with isoflurane and then killed by abdominal aortic exsanguination. The gastrocnemius and soleus leg muscles, and white adipose tissues (epididymal, mesenteric, perirenal + retroperitoneal and subcutaneous), were excised and weighed.

For Expt 3, rats were fed the casein or EWP diet and provided feed containing 5 or $10 \%$ maize oil (Table 2) for $28 \mathrm{~d}$ using a pair-feeding protocol (casein, maize oil $5 \%: n$ 6; EWP, maize oil 5\%: $n$ 6; casein, maize oil 10\%: $n$ 6; EWP, maize oil 10\%: $n$ 6). At the end of the final study day, the rats were subjected to 8-h fasting, anaesthetised with isoflurane and then killed by abdominal aortic exsanguination. The liver and white adipose tissues (epididymal, mesenteric, perirenal + retroperitoneal and subcutaneous) were excised and weighed.

The livers and white adipose tissues were kept at $-20^{\circ} \mathrm{C}$ until they were analysed. Blood was kept at room temperature for $30 \mathrm{~min}$ and then centrifuged at $1600 \mathrm{~g}$ for $10 \mathrm{~min}$ to collect the serum. The serum was kept at $-20^{\circ} \mathrm{C}$ until it was analysed. Samples for liver enzyme activity were prepared by homogenising the liver, centrifuging the homogenate at $500 \boldsymbol{g}$ for $10 \mathrm{~min}$, collecting the supernatant (a part of the supernatant such as the liver homogenate without nuclear fraction was stored at $-80^{\circ} \mathrm{C}$ until it was analysed) and centrifuging the supernatant at $100000 \boldsymbol{g}$ for $1 \mathrm{~h}$. The supernatant (the liver cytosolic fraction) from the last step was collected and stored at $-80^{\circ} \mathrm{C}$ until it was analysed ${ }^{(17)}$.

All experiments were conducted under the guidelines for Animal experiments at Kewpie Corporation and Law no. 105

Table 2. Composition of experimental diets*

\begin{tabular}{|c|c|c|c|c|}
\hline & \multicolumn{2}{|c|}{ Maize oil $5 \%(\mathrm{~g} / \mathrm{kg})$} & \multicolumn{2}{|c|}{ Maize oil $10 \%(\mathrm{~g} / \mathrm{kg})$} \\
\hline & Casein & EWP & Casein & EWP \\
\hline Casein & 200 & - & 200 & - \\
\hline Dried EWP & - & 200 & - & 200 \\
\hline Maize starch & 150 & 150 & 150 & 150 \\
\hline Cellulose & 50 & 50 & 50 & 50 \\
\hline Maize oil & 50 & 50 & 100 & 100 \\
\hline Mineral mixture (AIN-76) & 35 & 35 & 35 & 35 \\
\hline Vitamin mixture (AIN-76) & 10 & 10 & 10 & 10 \\
\hline DL-Met & 3 & 3 & 3 & 3 \\
\hline Choline bitartrate & 2 & 2 & 2 & 2 \\
\hline Sucrose & 500 & 500 & 450 & 450 \\
\hline Energy (kJ/100 g diet) & 1565 & 1565 & 1677 & 1677 \\
\hline Moisture ( $\mathrm{g} / 100 \mathrm{~g}$ diet) & 4.45 & 3.75 & $4 \cdot 41$ & $3 \cdot 71$ \\
\hline Protein (g/100 g diet) & $17 \cdot 7$ & $17 \cdot 7$ & $17 \cdot 7$ & $17 \cdot 7$ \\
\hline Carbohydrate (g/100 g diet) & 65.4 & 65.4 & $60 \cdot 4$ & $60 \cdot 5$ \\
\hline Fat (g/100 g diet) & $5 \cdot 41$ & $5 \cdot 19$ & $10 \cdot 4$ & $10 \cdot 2$ \\
\hline Ash (g/100 g diet) & 1.99 & $2 \cdot 81$ & 1.99 & $2 \cdot 81$ \\
\hline Fibre (g/100 g diet) & $5 \cdot 00$ & 5.00 & $5 \cdot 00$ & $5 \cdot 00$ \\
\hline
\end{tabular}


and Notification no. 6 of the Government of Japan. The authorisation number is 14-6.

\section{Analysis of morphometric and metabolic parameters}

Serum TAG, phospholipids, NEFA and glucose levels were measured using commercial enzyme assay kits from Wako Pure Chemicals (TAG E-test; Phospholipid C-test, NEFA C-test and GlucoseCII-test). Serum insulin and leptin concentrations were determined using commercial ELISA kits (Morinaga Insulin ELISA Kit or Morinaga Leptin ELISA Kit; Morinaga Institute of Biological Science, Inc.). Creatinine was analysed with a Creatinine Assay Kit (Biovision Co.) and ketone bodies with a $\beta$-hydroxybutyric acid (ketone body) Assay Kit (Cayman Chemical Co.).

Total lipids in the carcass (Expt 1) and the liver (Expt 3) were extracted using the method described by Folch et al ${ }^{(18)}$. Carcass protein content was analysed using the Dumas method ${ }^{(15)}$. The TAG and phospholipid content in the carcass and liver were determined using the methods described by Fletcher ${ }^{(19)}$ and Wooton $^{(20)}$, respectively.

Adipocyte size was measured as described elsewhere ${ }^{(21,22)}$. In brief, white adipose tissue was rinsed with a saline solution, fixed in a $10 \%$ neutral formalin-buffered saline solution and embedded in paraffin. The tissue was cut into $10-\mu \mathrm{m}$ sections and stained with haematoxylin to measure the cell size (100 cells/rat). The National Institutes of Health ImageJ software was used to measure cell size ${ }^{(23)}$. The DNA content of perirenal+ retroperitoneal adipose tissue was extracted using proteinase $\mathrm{K}$ followed by phenol/chloroform. The quantity of the DNA obtained was assessed by UV spectrophotometry at $260 \mathrm{~nm}$, as described elsewhere.

The enzymatic activities of carnitine palmitoyltransferase and acyl-CoA oxidase in the liver homogenates without the nuclear fraction were determined using the methods described by Ide et $a l{ }^{(17)}$. The enzymatic activities of fatty acid synthase, malic enzyme and glucose-6-phosphate dehydrogenase in the liver cytosolic fraction were determined using the methods described by Ide et $a l .^{(17)}$.

\section{Statistical analysis}

We expected a $\Delta$ body fat (\%) about 5 (\%) smaller in the EWP group than in the casein group based on the previous study by Ochiai \& Matsuo ${ }^{(24)}$. A SD of 1.5 of the higher value could be allowed. For a type 1 risk $\alpha$ of 0.05 and power (1- $\beta$ ) of $80 \%$, the sample size required was more than three per group.

All results are shown as the means with their standard errors. Comparisons between two groups were performed using Student's $t$ test (Table 3 of Expt 1, Table 4 and Fig. 1 of Expt 2). The effects of dietary protein source, dietary fat content and their interaction were analysed by two-way ANOVA (Table 5 of Expt 3). If an interaction was observed, it was analysed further by Tukey-Kramer multiple comparison post hoc test (Table 5 of Expt 3). Differences were considered significant at $P<0 \cdot 05$. Statistical analysis was performed using SPSS version 20 (IBM Japan Ltd).

\section{Results}

Effects of dietary egg-white protein on body fat and protein mass (Expt 1)

To assess the effect of EWP on body composition in rats, we analysed rat carcasses fed the casein or EWP diet. No significant differences in body weight increase, food intake and energy intake between the EWP and casein groups were observed (Table 3). The levels of protein and TAG were measured in the rat carcasses. The protein levels in the carcasses of the EWP group were significantly higher than that of the casein group (Table 3). In addition, the TAG levels in the EWP group were significantly lower than that of the casein group (Table 3). Finally, the sum of body protein and fat levels in carcasses was 28.1 (sE 0.5) and 28.1 (sE 0.7) $\mathrm{g}$ in the casein and EWP groups, respectively, which was not significantly different.

\section{Effect of dietary egg-white protein on adipocyte size (Expt 2)}

On the basis of the results of Table 3, we evaluated the effects of EWP on abdominal fat mass and adipocyte size in rats. No significant differences in body weight increase, food intake and energy intake between the EWP and casein groups were observed (Table 4). Perirenal + retroperitoneal and subcutaneous adipose tissue weights were significantly lower in the EWP group compared with the casein group. No significant differences in the epididymal and mesenteric adipose tissue weights between the EWP and casein groups were observed (Table 4).

The average adipocyte size in perirenal + retroperitoneal adipose tissue in the EWP group was smaller than that in the casein group. In addition, the number of small adipocytes was increased and the number of large adipocytes was decreased in the EWP group compared with the casein group (Table 4). The DNA content, used as an index of the number of cells in the perirenal + retroperitoneal adipose tissue, was significantly higher in the EWP group than in the casein group (Table 4). However, the liver TAG concentration was significantly lower in the EWP group than in the casein group (Table 4).

Table 3. Growth parameters and carcass contents of rats fed the casein or egg-white protein (EWP) diet (Expt 1)

(Mean values with their standard errors; $n$ 10/group)

\begin{tabular}{|c|c|c|c|c|}
\hline & \multicolumn{2}{|c|}{ Casein } & \multicolumn{2}{|c|}{ EWP } \\
\hline & Mean & SEM & Mean & SEM \\
\hline \multicolumn{5}{|l|}{ Growth parameter $(\mathrm{g} / \mathrm{d})$} \\
\hline Body weight gain & $7 \cdot 24$ & 0.09 & $7 \cdot 29$ & 0.18 \\
\hline Food intake & $17 \cdot 2$ & 0.1 & $16 \cdot 7$ & 0.4 \\
\hline Energy intake $(\mathrm{kJ} / \mathrm{d})$ & 288 & 2 & 280 & 5 \\
\hline \multicolumn{5}{|c|}{ Carcass contents ( $\mathrm{g} / 100 \mathrm{~g}$ body weight) } \\
\hline Protein & $18 \cdot 6$ & 0.2 & $20 \cdot 9$ & $0.5^{*}$ \\
\hline TAG & 9.57 & 0.72 & $7 \cdot 18$ & $0.63^{*}$ \\
\hline Phospholipids & 0.683 & 0.045 & 0.641 & 0.026 \\
\hline
\end{tabular}

Mean values were significantly different from those of the casein group: ${ }^{\star} P<0.05$. 
Table 4. Growth and morphometric parameters, adipocyte size and DNA contents in adipose tissue of rats fed the casein or egg-white protein (EWP) diet (Expt 2) (Mean values with their standard errors; $n$ 9-10/group)

\begin{tabular}{|c|c|c|c|c|}
\hline & \multicolumn{2}{|c|}{ Casein } & \multicolumn{2}{|c|}{ EWP } \\
\hline & Mean & SEM & Mean & SEM \\
\hline Body weight gain $(g / d)$ & $6 \cdot 74$ & 0.25 & 6.98 & 0.16 \\
\hline Food intake $(\mathrm{g} / \mathrm{d})$ & 17.8 & 0.2 & $17 \cdot 7$ & 0.2 \\
\hline Energy intake (kJ/d) & 298 & 6 & 298 & 3 \\
\hline Gastrocnemius leg muscle (g/100 g body weight) & 1.08 & 0.02 & $1 \cdot 15^{\star}$ & 0.02 \\
\hline Soleus leg muscle (g/100 g body weight) & 0.0663 & 0.0027 & 0.0644 & 0.0033 \\
\hline \multicolumn{5}{|l|}{ Fat mass ( $\mathrm{g} / 100 \mathrm{~g}$ body weight) } \\
\hline Epididymal & 1.55 & 0.10 & 1.38 & 0.08 \\
\hline Mesenteric & 0.944 & 0.044 & 0.856 & 0.053 \\
\hline Perirenal + retroperitoneal & $2 \cdot 38$ & 0.14 & $2 \cdot 02^{*}$ & 0.12 \\
\hline Total (abdominal fat) & 4.87 & 0.24 & $4 \cdot 25^{\star}$ & 0.23 \\
\hline Subcutaneous & 2.59 & 0.22 & $2.06^{*}$ & 0.20 \\
\hline \multicolumn{5}{|l|}{ Adipocyte size $\left(\mu \mathrm{m}^{2}\right)$} \\
\hline Perirenal + retroperitoneal & 4634 & 395 & $3209^{\star}$ & 213 \\
\hline \multicolumn{5}{|l|}{ DNA ( $\mu \mathrm{g} / \mathrm{g}$ tissue) } \\
\hline Perirenal + retroperitoneal & 238 & 21 & $332^{*}$ & 18 \\
\hline
\end{tabular}

${ }^{*}$ Mean value was significantly different from that of the casein group $(P<0.05)$.

\section{Effect of dietary egg-white protein on lipid metabolism in the liver (Expt 3)}

To identify the involvement of dietary fat levels in the rats, one of two fat levels ( 5 or $10 \%$ ) was added to their diet along with the different protein sources (EWP and casein). No significant difference in food intake and energy intake among the four groups was observed. The increase in body weight was significantly higher in rats given $10 \%$ maize oil than rats given $5 \%$ maize oil. Mesentery adipose tissue weight trended to being lower in the EWP group compared with the casein group $(P=0.06)$, and in the $5 \%$ maize oil group compared with the $10 \%$ maize oil group $(P=0.06)$. The perirenal adipose tissue weight was significantly lower in the EWP group compared with the casein group, whereas no significant difference between the 5 and $10 \%$ maize oil groups was observed. The testicular adipose tissue weight trended to being lower in the EWP group compared with the casein group $(P=0.06)$, and these values for the $5 \%$ maize oil group were significantly lower than in the $10 \%$ maize oil group. The total white adipose tissue weight was significantly lower for the EWP group compared with the casein group, and the 5\% maize oil group trended to having lower values than the $10 \%$ maize oil group (Table 5).

Serum TAG and NEFA concentrations were significantly lower following EWP consumption than after casein consumption. Serum insulin concentration was significantly higher after EWP consumption than after casein consumption, whereas significantly lower values were observed in the $5 \%$ maize oil group than in the $10 \%$ maize oil group. In addition, significantly lower leptin values were noted after EWP consumption than after casein consumption, whereas significantly higher values were observed in the $5 \%$ maize oil group than in the $10 \%$ maize oil group. Serum creatinine and $\beta$-hydroxybutyric acid concentrations were significantly lower after EWP consumption than after casein consumption, whereas the creatinine concentration was significantly lower in the $10 \%$ maize oil group than in the $5 \%$ maize oil group. No significant differences were observed for the serum phospholipids or glucose concentrations among the four groups (Table 5).

No significant differences in liver phospholipid concentration among the four groups were observed (Table 5). The liver TAG concentration was significantly lower in rats that were on the EWP diet compared with rats on the casein diet. In addition, significantly higher values for carnitine palmitoyltransferase and acyl-CoA oxidase activity in the liver were observed after EWP consumption than after casein consumption, and significantly lower malic enzyme activity was observed after EWP consumption than after casein consumption. Finally, with a $10 \%$ maize oil diet, glucose-6-phosphate dehydrogenase activity was significantly lower after EWP consumption than after casein consumption. However, no effect of EWP ingestion on fatty acid synthase activity was observed (Table 5).

\section{Discussion}

The results of this study indicate that the consumption of an EWP-based diet increases body protein by $12 \%$ and gastrocnemius leg muscle weight by $6 \%$, while decreasing body TAG levels by $25 \%$, abdominal fat by $12-18 \%$, subcutaneous fat by $20 \%$ and adipocyte size by $31 \%$ when compared with a casein-based diet (Tables 3-5, Fig. 1). The increase in the level of body protein following EWP consumption appears to be due to effects from its fractions, the amino acids that compose the proteins and the EWP component as a whole. The effect of EWP is likely to be because of its net protein utilisation of approximately $95 \%$, which is much higher than that of casein, which is $70 \%{ }^{(6,25)}$. It has been reported previously that ovalbumin and ovotransferrin from EWP fractions promote the growth of cultured muscle cells (C2C12 cells) ${ }^{(26)}$. In addition, the effects of the amino acids within EWP are likely because of the presence of branched amino acids in egg whites, which increase the branched amino acid concentrations in the blood when ingested $^{(27)}$. After exercise, the concentrations of these amino 
Table 5. Serum and hepatic lipid, and hepatic enzyme activity in rats fed casein and egg-white protein (EWP) on changing dietary fat level (5 or 10\%) (Expt 3) (Mean values with their standard errors; $n$ 6/group)

\begin{tabular}{|c|c|c|c|c|c|c|c|c|c|c|c|}
\hline & \multicolumn{4}{|c|}{ Maize oil $5 \%$} & \multicolumn{4}{|c|}{ Maize oil $10 \%$} & & & \\
\hline & \multicolumn{2}{|c|}{ Casein } & \multicolumn{2}{|c|}{ EWP } & \multicolumn{2}{|c|}{ Casein } & \multicolumn{2}{|c|}{ EWP } & \multicolumn{3}{|c|}{ Two-way ANOVA $(P)$} \\
\hline & Mean & SEM & Mean & SEM & Mean & SEM & Mean & SEM & Protein & Oil & Interaction \\
\hline \multicolumn{12}{|l|}{ Growth parameters $(\mathrm{g} / \mathrm{d})$} \\
\hline Body weight gain & $6 \cdot 15$ & 0.17 & $6 \cdot 28$ & 0.23 & 6.73 & 0.22 & 6.78 & 0.38 & NS & NS & NS \\
\hline Food intake & $17 \cdot 6$ & 0.0 & $17 \cdot 4$ & 0.4 & $17 \cdot 2$ & 0.3 & $16 \cdot 7$ & 0.6 & NS & NS & NS \\
\hline Energy intake $(\mathrm{kJ} / \mathrm{d})$ & 275 & 1 & 273 & 6 & 289 & 5 & 280 & 10 & NS & NS & NS \\
\hline \multicolumn{12}{|l|}{ Fat mass ( $\mathrm{g} / 100 \mathrm{~g}$ body weight) } \\
\hline Epididymal & 1.42 & 0.07 & $1 \cdot 27$ & 0.13 & 1.80 & 0.16 & 1.44 & 0.12 & 0.0570 & $<0.05$ & NS \\
\hline Mesenteric & 1.02 & 0.04 & 0.904 & 0.036 & $1 \cdot 15$ & 0.08 & 1.02 & 0.08 & 0.0641 & 0.0641 & NS \\
\hline Perirenal + retroperitoneal & 0.748 & 0.099 & 0.652 & 0.089 & 0.880 & 0.071 & 0.654 & 0.036 & 0.0504 & NS & NS \\
\hline Total (abdominal fat) & $3 \cdot 19$ & 0.19 & 2.82 & 0.22 & 3.82 & 0.28 & $3 \cdot 12$ & 0.21 & $<0.05$ & 0.0521 & NS \\
\hline \multicolumn{12}{|l|}{ Serum parameters } \\
\hline TAG (mg/100 ml) & 135 & 12 & $79 \cdot 8$ & $18 \cdot 1$ & 101 & 14 & $50 \cdot 9$ & 4.9 & $<0.05$ & NS & NS \\
\hline Phospholipids (mg/100 ml) & 158 & 2 & 159 & 13 & 149 & 11 & 138 & 14 & NS & NS & NS \\
\hline NEFA $(m E q / l)$ & 0.738 & 0.021 & 0.584 & 0.066 & 0.758 & 0.068 & 0.519 & 0.062 & $<0.05$ & NS & NS \\
\hline Glucose $(\mathrm{mg} / 100 \mathrm{ml})$ & 92.8 & 5.4 & 104 & 6 & 104 & 5 & 108 & 7 & NS & NS & NS \\
\hline Insulin (ng/ml) & 0.787 & 0.107 & 1.26 & 0.18 & 0.286 & 0.138 & 0.532 & 0.075 & $<0.05$ & $<0.05$ & NS \\
\hline Leptin (ng/ml) & 3.24 & 0.33 & 2.03 & 0.48 & 3.58 & 0.46 & 1.68 & 0.28 & $<0.05$ & $<0.05$ & NS \\
\hline \multicolumn{12}{|l|}{ Serum parameters } \\
\hline Creatinine $(\mathrm{nmol} / \mathrm{ml})$ & 9.94 & 0.42 & 6.93 & 0.29 & 6.66 & 0.52 & $5 \cdot 32$ & 0.27 & $<0.05$ & $<0.05$ & NS \\
\hline$\beta$-Hydroxybytyric acid (mg/ml) & 0.459 & 0.031 & 0.373 & 0.039 & 0.451 & 0.022 & 0.361 & 0.027 & $<0.05$ & NS & NS \\
\hline \multicolumn{12}{|l|}{ Hepatic lipids (mg/g liver) } \\
\hline TAG & 49.5 & 4.9 & $28 \cdot 0$ & 1.9 & 38.6 & 3.5 & 26.5 & $2 \cdot 6$ & $<0.05$ & NS & NS \\
\hline Phospholipids & $30 \cdot 6$ & 0.6 & $29 \cdot 3$ & 1.0 & 29.5 & 0.6 & 30.5 & 0.7 & NS & NS & NS \\
\hline \multicolumn{12}{|c|}{ Hepatic enzyme activity ( $\mathrm{nmol} / \mathrm{min}$ per $\mathrm{mg}$ protein) } \\
\hline CPT & $2 \cdot 89$ & 0.51 & 4.79 & 0.52 & 2.89 & 0.34 & 3.95 & 0.26 & $<0.05$ & NS & NS \\
\hline $\mathrm{ACO}$ & $2 \cdot 35$ & 0.35 & 3.95 & 0.33 & 3.32 & 0.49 & 4.62 & 0.33 & $<0.05$ & NS & NS \\
\hline FAS & $7 \cdot 21$ & 0.72 & $7 \cdot 19$ & 0.41 & 7.49 & 0.50 & $7 \cdot 70$ & 0.32 & NS & NS & NS \\
\hline G6PDH & 54.8 & $4 \cdot 8^{\mathrm{a}}$ & 31.4 & $3 \cdot 3^{\mathrm{b}}$ & $27 \cdot 1$ & $3.3^{b}$ & $26 \cdot 4$ & $2 \cdot 7^{\mathrm{b}}$ & $<0.05$ & $<0.05$ & $<0.05$ \\
\hline ME & $30 \cdot 9$ & $3 \cdot 1$ & 24.3 & 1.3 & 24.0 & 1.4 & 14.8 & $2 \cdot 2$ & $<0.05$ & $<0.05$ & NS \\
\hline
\end{tabular}

CPT, carnitine palmitoyltransferase; ACO, acyl-CoA oxidase; FAS, fatty acid synthase; G6PDH, glucose-6-phosphate dehydrogenase; ME, malic enzyme.

a,b Mean values within a row with unlike superscript letters were significantly different $(P<0.05)$ by Tukey-Kramer multiple comparison post hoc test. 
(a)

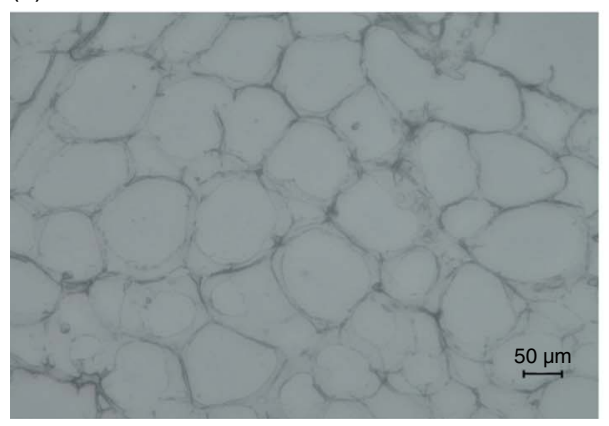

(c)

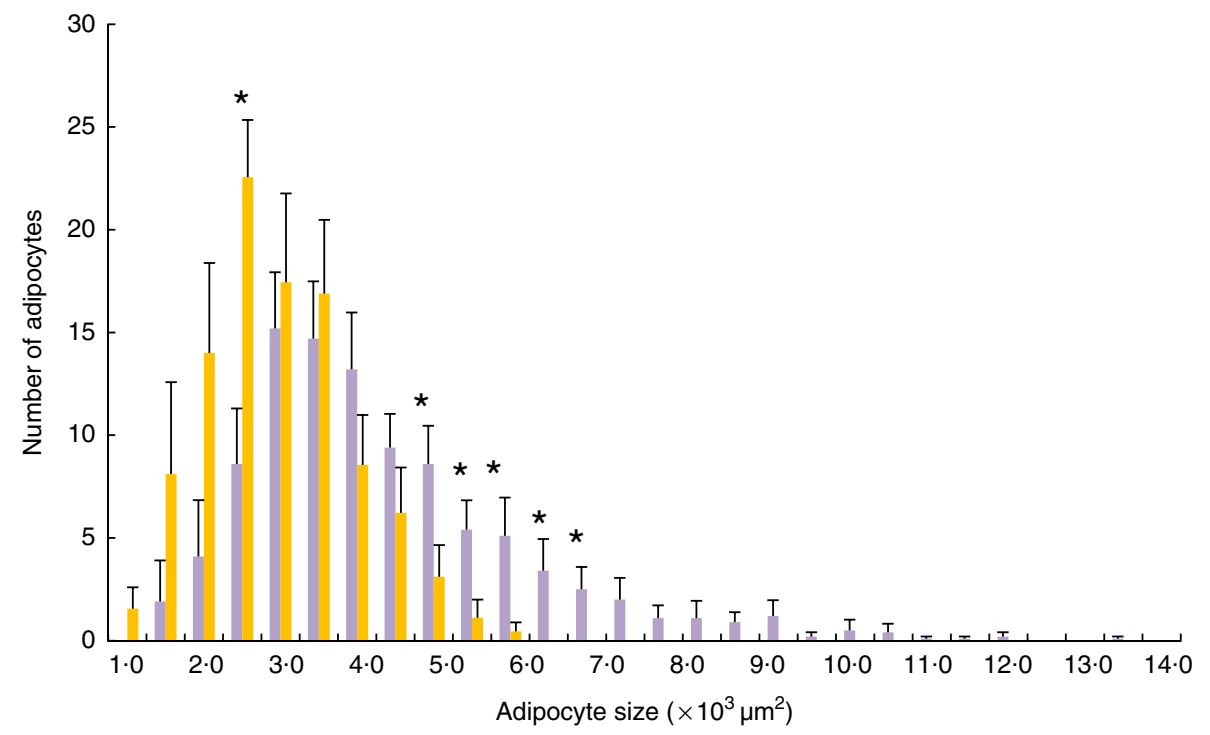

(b)

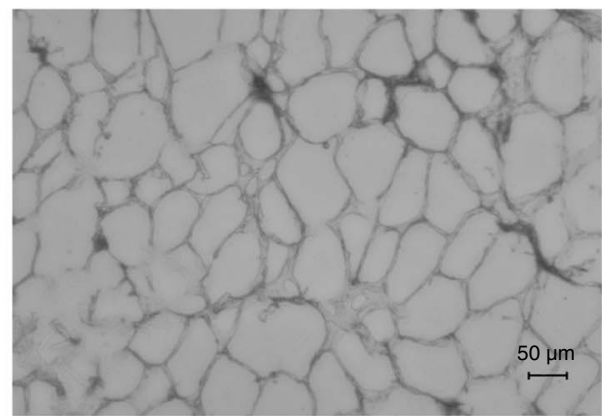

Fig. 1. Effects of dietary egg-white protein (EWP) on cell size in white adipose tissue. Adipocytes are shown in paraffin sections of perirenal + retroperitoneal adipose tissue (scale bar: $50 \mu \mathrm{m}$ ). Casein group (a), EWP group (b). Profile of the distribution of cell size for adipocytes from perirenal + retroperitoneal adipose tissue (c). Values are means ( $n$ 9-10 rats/group), with their standard errors. c: $\square$, Casein; $\square$, EWP. Student's $t$ test between the casein and EWP groups: ${ }^{*} P<0.05$.

acids decrease ${ }^{(27)}$, and it is possible that after exercise the branched amino acids in EWP are used for muscle repair and hypertrophy. Consistent with this, the combination of strength training and EWP ingestion has been found to increase muscle mass and strength ${ }^{(28)}$, and egg whites are thus considered to be an effective source of protein for body building.

An increase in body protein in rat carcasses following EWP consumption with a high-fat diet has also been reported by Ochiai \& Matsuo ${ }^{(24)}$. They also noted that EWP ingestion decreased body fat, although the effect was not as clear. In their study, the food intake amount was significantly lower in rats fed EWP compared with rats fed casein. Because body fat is affected by the overall amount of food and lipids consumed, the decrease in body fat expected in that study would be because of the reduction in energy and lipid ingestion, and thus could not be attributed to EWP consumption. In our experiments, we used a pair-feeding strategy to match the food intake amount. Therefore, as equivalent food intake was accounted for, it was possible to determine that EWP consumption was responsible for increasing body protein and decreasing body fat. In addition, the combined weight of body protein and fat were roughly equivalent for the casein and EWP groups in this study, lending further support that EWP can promote a gain in body protein and reduction in body fat.

Previously, it was reported that daily ingestion of $15 \mathrm{~g}$ of EWP by male subjects performing a mild resistance exercise led to an increase in their muscle mass ${ }^{(28)}$. Although muscles typically do not increase in size unless they are exercised, muscle mass increased in our study for an unknown reason. For example, the consumption of EWP led to an increase in gastrocnemius muscle mass, when compared with consumption of casein. It is possible that the protein increase provided by the diets in this study, particularly the EWP diet, led to a decrease in abdominal fat because protein contributes heavily to the increase in muscle mass, and muscles are the site of fat combustion. However, serum creatinine levels, which are related to muscle energy metabolism, were not elevated in this study even though this would be expected if fat combustion in the muscles was increased $^{(29)}$. In contrast, the levels of $\beta$-hydroxybutyric acid, a ketone body, were significantly decreased in the rats fed EWP compared with the rats fed casein (Table 5). Serum ketone bodies levels reflect the balance between the rate of hepatic 
ketogenesis and the rate of ketone body utilisation in extrahepatic tissues and organs, such as skeletal muscle, heart and brain $^{(30)}$. Therefore, the increase of protein in skeletal muscle could have led to increased utilisation of ketone bodies followed by a decrease in serum $\beta$-hydroxybutyric acid levels. In addition, our findings indicate that there is an increase in the activity of enzymes related to $\beta$-oxidation in the liver and a decrease in liver TAG levels following consumption of an EWP-based diet (Table 5). Therefore, the decrease in liver TAG might cause an increase in the activity of liver $\beta$-oxidation enzymes after the ingestion of EWP. In the future, it will be necessary to examine whether liver $\beta$-oxidation is regulated in this manner, using gene analysis or other methods.

Another possible mechanism through which EWP may have exerted its abdominal-fat-lowering effect is the suppression of lipid absorption into abdominal fat cells. We previously reported that EWP can suppress lipid absorption and lymphatic lipid transport $20 \%$ more than casein does ${ }^{(31)}$, which is important because food ingredients effective at suppressing TAG absorption, such as indigestible dextrin and catechin, have been shown to reduce abdominal $\mathrm{fat}^{(32-36)}$. The mechanism underlying the difference in inhibition is likely that the water-holding capacity, settling volume and viscosity are higher in the degradation products of EWP pepsin hydrolysate than in those of casein pepsin hydrolysate ${ }^{(31)}$. However, there are likely other mechanisms involved, because the suppression of TAG absorption was higher than the suppression of cholesterol absorption.

An additional possible mechanism that could have contributed to the abdominal-fat-lowering effect we observed surrounds the EWP ovalbumin. It is known that ovalbumin binds to fatty acids $^{(37)}$ and that unheated ovalbumin is minimally degraded by pepsin ${ }^{(38)}$, and therefore it can reach the small intestine largely intact. Moreover, EWP inhibit lipase $\operatorname{activity}^{(39)}$ and a small amount of NEFA produced by the action of lipase suppress lipid absorption by binding to ovalbumin. In this study, we used unheated egg white, but ovalbumin in heated egg whites is known to be more susceptible to degradation by pepsin ${ }^{(38)}$. For this reason, confirmation of the abdominal-fat-lowering effect we observed here using heated egg whites would help to clarify that the observed effect was due to an inhibition of lipid absorption.

We also observed an abdominal fat mass reduction of approximately 10-20\% (Tables 2 and 3). Therefore, abdominal fat mass appears to be highly influenced by the inhibition of lipid absorption. However, the suppression of lipid absorption is insufficient to explain the reduction in the size of abdominal adipocytes we observed, because the ingestion of EWP caused a decrease in the area of abdominal adipocytes by approximately $30 \%$ in comparison with casein (Fig. 1). Therefore, the reduction in the size of abdominal adipocytes following the ingestion of EWP is likely to be due to the suppression of lipid absorption, an increase of body protein mass and enhancement of liver $\beta$-oxidation. The reduction of abdominal adipocytes may also occur because of cellular events caused by direct action of amino acids and/or peptides. For example, thiazolidinedione derivatives have been reported to reduce the size of abdominal adipocytes by inducing expression of the $P P A R \gamma$ gene $^{(40)}$. This would be an interesting avenue for future investigation that we did not perform here, because we could not perform an assay of gene expression within abdominal fat in this study.

The effective dose of EWP in humans is unknown. It has been reported that daily ingestion of $5 \mathrm{~g}$ of $\beta$-conglycinin leads to a reduction of abdominal fat ${ }^{(14)}$. Given that EWP (i.e. ovalbumin, ovotransferrin and lysozyme) reduce abdominal fat ${ }^{(31)}$, daily ingestion of approximately $8 \mathrm{~g}$ of EWP, equivalent to a total of $5 \mathrm{~g}$ of these three fractions, should successfully reduce abdominal fat. This may not be possible in practice, because it is known that adverse effects, including the development of allergies and biotin deficiency, can occur. However, we believe that avidin likely undergoes degradation by pepsin, because the avidin band disappears in SDS-PAGE after a reaction with pepsin ${ }^{(38)}$, and that there is unlikely to be a problem unless biotin is ingested in conjunction with egg white. Moreover, low-allergen egg white free of ovomucoid is available, so this type of egg white might exert the abdominal-fat-lowering effect at a lower amount than regular egg white.

Increase of abdominal fat is a risk factor for arteriosclerotic diseases, because it induces symptoms such as dyslipidaemia, glucose intolerance and hypertension ${ }^{(7)}$. To gain the benefits of EWP, it may be preferable to ingest only egg whites in processed foods, because it allows one to ingest only egg white as opposed to the whole egg. However, products using egg whites are readily available in the market, as egg white is utilised in most foods manufactured today. Ultimately, the successful clarification of an abdominal-fat-lowering effect of EWP will lead to the successful utilisation of EWP as a nutraceutical that could prevent the metabolic syndrome.

\section{Acknowledgements}

The authors thank Enago (www.enago.jp) for English language editing. The authors thank Professor Michihiro Sugano (Kyushu University and Prefectural University of Kumamoto) and Kazunori Utsunomiya (The Jikei University) for providing technical advice.

Experimental work in Kyushu University was supported by Kewpie Corporation (Tokyo, Japan).

R. M., B. S., M. U., M. F. and A. M. performed experiments and analysed the data. B. S., Y. M., M. K. and M. S. supervised the study design and commented on the manuscript. R. M. and B. S. wrote the manuscript. All authors read and approved the final manuscript.

R. M., A. M., Y. M. and M. K. are employees of Kewpie Corporation. There are no other patents, products in development or marketed products to declare. All other authors have no conflicts of interest to declare.

\section{References}

1. Kido T, Shizuka F, Shimomura Y, et al. (2013) Dietary reference intake for Japanese 2010: protein. J Nutr Sci Vitaminol 59, 836-843.

2. Rosenberg IH (1997) Sarcopenia: origins and clinical relevance. J Nutr 127, 990S-991S.

3. Houston DK, Nicklas BJ, Harris TB, et al. (2008) Dietary protein intake is associated with lean mass change in order, 
community-dwelling adults: the health, aging, and body composition (Health ABC) study. Am J Clin Nutr 87, 150-155.

4. Lin CP \& Huang PC (1986) Comparison of control diets containing various protein levels for determining net protein utilization by rats. J Nutr 116, 216-222.

5. World Health Organization (1985) Energy and Protein Requirements. Report of a Joint FAO/WHO/UNU Expert Consultation. WHO Technical Report Series, no. 724. Geneva: WHO.

6. Sheffner AL, Eckfeldt GA \& Spector H (1956) The pepsin-digest-residue (PDR) amino acid index of net protein utilization. J Nutr 60, 105-120.

7. Alberti KG \& Zimmet PZ (1998) Definition, diagnosis and classification of diabetes mellitus and its complications, part 1: diagnosis and classification of diabetes mellitus provisional report of a WHO consultation. Diabet Med 15, 539-553.

8. Kato Y, Hamasaki T, Sato S, et al. (2014) Relationship between the attitudes towards improving eating habits and prevalence of metabolic syndrome. Data from the 2005 National Health and Nutrition Survey and the comprehensive survey of living conditions. Nibon Koshu Eisei Zasshi 61, 385-395.

9. Frisch RE, Hegsted DM \& Yoshinaga K (1977) Carcass components at first estrus of rats on high-fat and low-fat diets: body water, protein, and fat. Proc Natl Acad Sci U S A 74, 379-383.

10. Nagao T, Hase T \& Tokimitsu I (2007) A green tea extract high in cathechins reduces body fat and cardiovascular risks in humans. Obesity (Silver Spring) 15, 1473-1483.

11. Akazome Y, Kametani N, Kanda T, et al. (2010) Evaluation of safety of excessive intake and efficacy of long-term intake of beverages containing apple polyphenols. J Oleo Sci 59, 321-338.

12. Takeuchi H, Sekine S, Kojima K, et al. (2008) The application of medium-chain fatty acids: edible oil with suppressing effect on body fat accumulation. Asia Pac J Clin Nutr 17, 320-323.

13. Ono T, Murakoshi M, Suzuki N, et al. (2010) Potent antiobesity effect of enreric-coated lactoferrin: decrease in visceral fat accumulation in Japanese men and women with abdominal obesity after 8-week administration of enteric coated lactofferin tablets. Br J Nutr 104, 1688-1695.

14. Kohno M, Hirotsuka M, Kito M, et al. (2006) Decreases in serum triglycerol and visceral fat mediated by dietary soybean beta-conglycinin. $J$ Atheroscler Thromb 13, 247-255.

15. Stitcher JE, Jolliff CR \& Hill RM (1969) Comparison of dumas and kjeldahl kethods for determination of nitrogen in faces. Clin Chem 15, 248-254.

16. American Institute of Nutrition (1977) Report of the American Institute of Nutrition ad hoc committee on standards for nutritional studies. J Nutr 107, 1340-1348.

17. Ide $T$, Murata $M$ \& Sugano M (1996) Stimulation of the activities of hepatic fatty acid oxidation enzyme by dietary fat rich in $\alpha$-linolenic acid in rat. J Lipid Res 37, 448-463.

18. Folch J, Lee M \& Stanley GHS (1957) A simple method for the isolation and purification of total lipids for animal tissue. $J$ Biol Chem 226, 497-509.

19. Fletcher MJ (1968) A carorimetric method for estimating serum triglycerides. Clin Cbim Acta 22, 393-397.

20. Wooton DG (1977) Semiautomated spectrophotometry of total phospyolipids in plasma. Clin Chem 23, 1766-1768.

21. Sato M, Uzu K, Yoshida T, et al. (2008) Effects of milk fermented by Lactobacillus gasseri SBT2055 on adipocyte size in rats. Br J Nutr 99, 1013-1017.

22. Caiou B, Harmelen KV, Duran-Sandoval D, et al. (2006) The farnesoid $\mathrm{X}$ receptor modulates adiposite and peripheral insulin sensitivity in mice. J Biol Chem 281, 11039-11049.
23. Tong LT, Katakura Y, Kawamura S, et al. (2010) Effects of Kurozu concentrated liquid on adipocyte size in rats. Lipids Health Dis 9, 134.

24. Ochiai M \& Matsuo $T$ (2014) Effect of egg white and its hydrolysate on stearoyl-CoA desaturase index and fat accumulation in rat tissue. Int J Food Sci Nutr 65, 948-952.

25. Tagle MA \& Donoso G (1965) Net protein ulitization determined in short- and long-term experiments with rats. J Nutr 87, 173-178.

26. Mizunoya W, Tashima A, Sato Y, et al. (2015) The growthpromoting activity of egg white proteins in the C2C12 myoblast cell line. Anim Sci J 86, 194-199.

27. Kato Y, Numao S, Miyauchi R, et al. (2010) Effect of intermittent blood volume fluctuation of light resistance exercise after ingestion of the high protein snacks on plasma branched chain amino acid concentrations in young adults. $J$ Nutr Sci Vitaminol 56, 255-259.

28. Kato Y, Sawada A, Numao S, et al. (2011) Chronic effects of light resistance exercise after ingestion of a high-protein snack on increase of skeletal muscle mass and strength in young adults. J Nutr Sci Vitaminol 57, 233-238.

29. Patel SS, Molnar MZ, Tayek JA, et al. (2013) Serum creatinine as a marker of muscle mass in chronic kidney disease: results of a cross-sectional study and review of literature, L. J Cachexia Sarcopenia Muscle 4, 19-29.

30. Fabbrini E \& Magkos F (2015) Hepatic steatosis as a marker of metabolic dysfunction. Nutrients 7, 4995-5019.

31. Matsuoka R, Shirouchi B, Kawamura S, et al. (2014) Dietary egg white protein inhibits lymphatic lipid transport in thoracic lymph duct-cannulated rats. J Agric Food Chem 62 , 10694-10700.

32. Ikeda I, Tsuda Y, Suzuki Y, et al. (2005) Tea catechins with a galloyl moiety suppress postprandial hypertriglycerolemia by delaying lymphatic transport of dietary fat in rats. J Nutr $\mathbf{1 3 5}$, $155-159$.

33. Unno T, Tago M, Suzuki Y, et al. (2005) Effect of tea catechins on postprandial plasma lipid responses in human subjects. Br J Nutr 93, 543-547.

34. Kajimoto O, Kajimoto Y, Yabune M, et al. (2005) Tea catechins with a galloyl moiety reduce body weight and fat. J Health Sci 51, 161-171.

35. Kametani N, Asakura R, Mitsuda H, et al. (2009) Effects of mixing tea beverage containing resistant maltodextrin om postprandial serum triglyceride and safety evaluation on longterm or excessive intake of the beverage. Jpn J Food Chem Safety 16, 20-27.

36. Kishimoto Y, Wakabayashi S \& Tokunaga K (2000) Effects of long-term administration of indigestible dextrin on visceral fat accumulation. J Jpn Assoc Dietary Fiber Res 4, 59-65.

37. Handa A, Gennadios MA, Hanna CL, et al. (1999) Physical and molecular properties of egg-white lipid films. J Food Sci 64 , 860-864.

38. Sakai K, Ushiyama Y \& Manabe S (1999) Peptic and pancreatic digestibility of raw and heat-treated hen's egg white protein. Jpn J Pediatr Allegy Clin Immunol 13, 36-42.

39. Gargouri Y, Julien R, Sugihara A, et al. (1984) Inhibition of pancreatic and microbial lipase by proteins. Biochim Biophys Acta 795, 326-331.

40. Okuno A, Tamemoto H, Tobe K, et al. (1998) Troglitazone increases the number of small adipocytes without the change of white adipose tissue mass in obese Zucker rats. J Clin Invest 101, 1354-1361. 